\title{
Review
}

\section{Undoing the demos: Neoliberalism's stealth revolution}

\author{
Wendy Brown \\ Zone Books, New York, 2015, 296pp., \$29.95/£20.95 (hc), ISBN: 978-1935408536 \\ Contemporary Political Theory (2016) 15, e11-e14. doi:10.1057/cpt.2015.38; \\ published online 30 June 2015
}

Undoing the Demos argues that 'neoliberalism is profoundly destructive to the fiber and future of democracy in any form' (p. 9). More precisely, it is concerned with mapping the myriad ways in which neo-liberalism, conceived as a productive mode of reason that today saturates ever more spheres of life, articulates crucial elements of democratic language, practice and subjectivity 'according to a specific image of the economic' (p. 10). In so doing neo-liberalism directly assaults the democratic imaginary that animated so much of modernity, hollowing out liberal democratic practices and institutions while at the same time cauterising radical democratic expressions.

Undoing the Demos is divided into two parts: the first, 'Neoliberal Reason and Political Life', puts forward the book's main argument and is moreover concerned with Michel Foucault's account of neo-liberalism, developed in his 1978-1979 lectures at the Collège de France, and discusses its merits and its shortcomings in detail; the second, 'Disseminating Neoliberal Reason', is concerned with how neo-liberal rationality is extended to spheres heretofore untouched by economic parameters, including 'statecraft and the workplace, ... jurisprudence, education, culture, and a vast range of quotidian activity' (p. 17). The central argument of the book is that 'neoliberalism assaults the principles, practices, cultures, subjects, and institutions of democracy understood as rule by the people' (p. 9). Brown sets out to understand how it does so and develops a theoretical framework, deeply reliant upon, but not uncritical of, Foucault's seminal account.

In the first chapter Brown does the theoretical legwork upon which the entire argument rests. While democracy is understood simply (and, in my view, problematically - an issue I will return to below) as 'rule by the people' (p. 19; cf. pp. 9, 20, 178, 202, 209), neo-liberalism is understood, with Foucault, as 'a distinctive mode of reason, of the production of subjects, a "conduct of conduct", and a scheme of valuation' (p. 21). Neo-liberalism, then, is not the name given to capitalism's latest guise, nor is it an ideology that masks the resurgence of class

(C) 2016 Macmillan Publishers Ltd. 1470-8914 Contemporary Political Theory Vol. 15, 2, e11-e14 www.palgrave-journals.com/cpt/ 
politics. Instead, it is conceptualised as a mode of reason, a 'political rationality' (pp. 20-21; cf. Chapter 4), that today invades all spheres of life and recasts in an economic register their constituent concepts, practices, institutions, subjects and truths. Accordingly, the book is not concerned with studying neo-liberal techniques of government, but with the rationality, the regime of truth, that underlies them.

Chapters 2 and 3 offer a systematic reading of Foucault's lectures on neo-liberalism (later published as The Birth of Biopolitics) and lead to a number of significant insights that expand the Foucauldian approach beyond his own groundwork. Importantly, Brown signals no less than 12 features of the contemporary neo-liberal landscape that Foucault could not account for because they either did not yet exist or were still only nascent (pp. 70-72). These include the rise of finance capital, permanent financial and social crises and crisis-fuelled austerity politics, the rise of governance, and, for Brown perhaps most profound, a number of changes within the neo-liberal subject, who is now tethered to competitive markets in such a way that she has lost all remnants of protection against brutal and impersonal market forces. This last feature is related to what Brown takes to be the biggest flaw in Foucault's analysis: it is not attentive towards homo politicus and its subsequent extinction by neo-liberal reason. Homo politicus, referred to as the 'demotic subject' (p. 87), theorised first by Aristotle, whose morphology changes continuously throughout her odyssey through occidental thought - via, inter alia, Locke, Smith, Bentham, Marx and Freud (see pp. 87-99) - is finally usurped by homo oeconomicus. When the economic subject reigns, what is vanquished is the form of subjectivity that animates democracy - a member of a demos, a democratic citizen, an autonomous, sovereign, Kantian subject.

Chapters 4, 5 and 6 - which make up the second part of the book - map the different ways in which neo-liberal rationality is disseminated through legal reason (Chapter 5) and through higher education (Chapter 6). This dissemination is made easier by contemporary governance practices (discussed in Chapter 4), which are 'not identical with or exclusive to neoliberalism' (p. 122). In other words: governance is not born of neo-liberal rationality, but once articulated to it, gives rise to novel ways of managing and disciplining subjects, states and firms. Governance practices thus provide the tools through which neo-liberal reason flows smoothly from sphere to sphere, including devolution, responsibilisation, 'benchmarking' and 'best practices' (see pp. 131-142). Through meticulous analysis of legal jargon, Brown shows, in Chapter 5, how the US Supreme Court opinions have in recent years been saturated with neo-liberal reason, thus assisting in discursively reconstructing democracy both at home and abroad. She further maps, in Chapter 6, how neo-liberalised higher education undercuts the formation of a critical, educated citizenry, without which democracy cannot survive.

Because its main aim is to study neo-liberal rationality, which has not been studied so rigorously before, Undoing the Demos is a timely and innovative book. At the same time, however, its scope invites some issues that have, on different levels and in 
different ways, a negative bearing on the strength of the argument. One such problem is that because Brown sets out primarily to understand neo-liberal rationality and how it is disseminated she pays little or no attention to elements that, although they fall outside of this scope, are arguably intimately related to the problem of rationality. For instance, the book does not engage in much depth with the problem of resistance to neo-liberalism (see pp. 220-222); with other de-democratising rationalities and their relationship to neo-liberal rationality; or with those theorists who were crucial in shaping the discursive framework from which neo-liberal rationality now draws (Röpke, Eucken, Hayek, Friedman, Becker and so on). The point is not so much that Brown should have investigated all of these separate issues, but that she provides few to no conceptual tools for investigating them or their relationship to neo-liberal rationality either.

A related concern is that Undoing the Demos is all-too-narrowly focused on a specific and contemporary (Anglo-)American form of neo-liberalism. While Brown acknowledges at the outset that she is aware of neo-liberalism's internal complexity and heterogeneity (see pp. 20-21) the rest of the book falls short of developing a convincing account of how neo-liberal rationality functions when it enters into different contexts. This is a book about present-day North American neo-liberalism, and little work is done to move outside of that context, even to Europe, let alone the rest of the world. Accordingly, Brown's ahistorical and geographically limited approach cannot explain how the neo-liberalisation of, for instance, British universities has insidiously merged with the already deeply entrenched class-based education system. Likewise, the reader is left guessing whether legal reason has been neo-liberalised in, for instance, Northern Europe in the same way as it has in the United States. Here again the point is not that Undoing the Demos should have been a book about contextually specific neo-liberalisms, but that it remains silent on the question of how neo-liberal rationality takes shape when it is inserted into the messy and complex landscape of micro-politics, where it will inevitably have to negotiate with pre-existing discourses or with stubborn remnants of previously hegemonic rationalities.

A final objection revolves around the notion of democracy and how Brown defines it. In defining democracy as 'rule by the people' Brown deliberately sticks to an 'open and contestable' (p. 20) understanding of democracy in order to show not just how a specific model of democracy (liberal, social, deliberative, elitist and so on), but also how 'the bare promise of bare democracy' (p. 203) tout court is undone. There are several problems with such a strategy. First, the Greek $\delta \eta \mu о \kappa \rho \alpha \tau i ́ \alpha$ does not straightforwardly translate into 'rule by the people', as Brown says it does (see pp. 19, 202), grounding the argument in a problematic claim from the start. Second, Brown wants to show that neo-liberalism is destructive of 'democracy in any form', meaning that it undermines the 'bare promise of bare democracy'. However, it could be argued that this promise is not at all shared by all forms of democracy: Does Schumpeterian elitist democracy really promise that 'all might be regarded as ends, rather than means' or that 'all may have a political voice' (p. 203)? Notwithstanding 
Brown's insistence on the openness of her definition, we appear to still be talking about quite a specific conception of democracy. Third, because of her definition, Brown's primary focus is on the people that ought to rule - that is, on demotic subjectivity and the exercise of sovereignty. Yet this focus cannot capture how neo-liberal rationality rearticulates notions outside of that definition, such as, to name but one element, the legitimacy of the legislature (which surely is different both from the legitimacy of the state and from popular sovereignty, which Brown does discuss because they do fit inside the scope of her definition). Brown's open and contestable definition, in brief, in fact limits her scope and thus the force of her argument.

While I think Undoing the Demos would have been all the better for pre-empting these issues, the book's merits outweigh these shortcomings. Besides providing a theoretical framework that allows for a deep understanding of neo-liberal rationality, it does so accessibly. More than merely speaking to Brown's comrades-in-arms on the Left, the book appears to be written for a broader audience and Brown's familiar style - lucid and rhythmic yet rigorous - makes even intricate Foucauldian claims easily digestible.

Undoing the Demos conveys a sober and mournful message: democracy is under attack and it might not survive. The book will leave anyone looking for strategies of resistance disappointed. But whoever wants to understand the rationality that informs and governs so much of our lives today would do well to read it.

Lars Cornelissen University of Brighton, Brighton BN2 4AT, UK 